\title{
EVALUATION OF CORN HYBRIDS UNDER CONTRASTING WATER AVAILABILITY CONDITIONS ${ }^{1}$
}

\author{
WILIAN HENRIQUE DINIZ BUSO ${ }^{2} *$, EMMANUEL ARNHOLD 3
}

\begin{abstract}
The current study aimed to assess adaptability and stability of corn hybrids regarding grain yields when sown in three different seasons in the Brazilian cerrado. The research was carried out at the Experimental Farm of the IF Goiano, campus in Ceres - GO. Pre-sowing fertilization was made with $20 \mathrm{~kg} \mathrm{ha}^{-1}$ of nitrogen, $150 \mathrm{~kg} \mathrm{ha}^{-1}$ of phosphorus and $80 \mathrm{~kg} \mathrm{ha}^{-1}$ of potassium (04-30-16 formulation). Data were analyzed in a random block experimental design. We assessed tem corn hybrids (Truck, Fórmula, P30F53, P3646H, P30F35H, AGN 30A77H, AGN 30A37H, AG 8088PRO, DKB 390 and DKB Bi9440) in three sowing seasons (Nov. 18, 2011; Jan. 31, 2012 and Feb. 20, 2012) with three replications. Harvests were held on Apr. 4, 2012; Jun. 10, 2012 and Jul. 1, 2012. Each hybrid were assessed on yielding; and a graphical analysis was made to contrast hybrids and sowing seasons regarding stability and adaptability. Results showed a significant effect of the interaction between hybrids and sowing times. Therefore, we may state that the best hybrid in an environment would not be necessarily good in another. Thereby, we can infer that drought and corn genetic variability have diverse behaviors in each season. Over the two-dimensional graphics generated by GGE Biplot method, we observed an increased adaptability of AGN 30A77H when sown on Nov. 18, 2011 and on Jan. 31, 2012, followed by Fórmula; however, for P30F35H, it was on Feb. 20, 2012.
\end{abstract}

Keywords: Adaptability. Stability. Drought.

\section{AVALIAÇÃO DE HÍBRIDOS DE MILHO EM ÉPOCAS CONTRASTANTES PARA DISPONIBILIDADE HÍDRICA EM GOIÁS}

\begin{abstract}
RESUMO - Com o presente trabalho objetivou avaliar a adaptabilidade e estabilidade para o rendimento de grãos de híbridos de milho cultivados em três épocas de semeadura no Município de Ceres, no bioma Cerrado em Goiás. A pesquisa foi realizada na Fazenda Experimental do IF Goiano Campus Ceres. A adubação de semeadura foi de $20 \mathrm{~kg} \mathrm{ha}^{-1}$ de nitrogênio, $150 \mathrm{~kg} \mathrm{ha}^{-1}$ de fósforo e $80 \mathrm{~kg} \mathrm{ha}^{-1}$ de potássio (fórmula 04-30-16). $\mathrm{O}$ delineamento experimental utilizado foi o de blocos ao acaso. Avaliou-se dez híbridos (Truck, Fórmula, P30F53, P3646H, P30F35H, AGN 30A77H, AGN 30A37H, AG 8088PRO, DKB 390 e DKB Bi9440) em três épocas de semeadura (18/11/2011,31/01/2012 e 20/02/2012) com três repetições. As colheitas foram realizadas em 04/04/2012, 10/06/2012 e 01/07/2012. Avaliou-se a produtividade e realizou a análise gráfica dos híbridos e épocas de semeadura para avaliar a estabilidade e adaptabilidade. Ocorreu efeito significativo para a interação híbridos $\mathrm{x}$ épocas de semeadura. Este resultado indica que o melhor híbrido em um ambiente não necessariamente será o melhor em outro. Pode-se inferir que o déficit hídrico e a variabilidade genética dos híbridos resultaram em comportamentos diferentes conforme se alterou a época de semeadura. Com os gráficos bidimensionais obtidos pela técnica GGE Biplot observou que o híbrido AGN 30A77H tem maior adaptabilidade ás épocas 18/11/2011 e 31/01/2012, seguido pelo híbrido Fórmula. E o híbrido P30F35H teve maior adaptabilidade a época 20/02/2012.
\end{abstract}

Palavras-chave: Adaptabilidade. Estabilidade. Stress hídrico.

\footnotetext{
*Corresponding author

${ }^{1}$ Received for publication in $08 / 25 / 2014$; accepted in $05 / 11 / 2016$.

Paper extracted from the research project of the first author.

${ }^{2}$ Department of Plant and Animal Sciences, Instituto Federal Goiano Campus Ceres, Ceres, GO, Brazil; wilian.buso@ifgoiano.edu.br.

${ }^{3}$ Department of Animal Sciences, Universidade Federal de Goiás, Goiânia, GO, Brazil; emmanuelarnhold@yahoo.com.br.
} 


\section{INTRODUCTION}

Corn (Zea mays L.) is widely adapted and can be grown from north to south of Brazil, in every month of the year. This crop is the most used in rotation and succession systems with other crops, with so prominent role in national agriculture. However, until nowadays, corn has been grown under poor technological levels, and using outdated spacing and fertilization recommendations (MENDES et al., 2012). Compared to other countries, average corn yield in Brazil is low. The United States and France have the highest productivity ranging from eight to nine tons $\mathrm{ha}^{-1}$ (USDA, 2014). In Brazil, annual corn yield for the 2014/ 2015 season was of $5382 \mathrm{~kg} \mathrm{ha}^{-1}$ (CONAB, 2016).

Grain yield potential of a crop depends on genetic and management factors as well as favorable environmental conditions. Variations in air temperature, radiation and water availability influence plant phenology, growth and development. Thus, as a genotype-environment interaction, grain yield potential can be maximized by choosing a proper time for sowing without burdening significantly the production costs (TOLLENAAR; LEE, 2002).

Water deficit can lead to marked declines in plant performance, depending on its intensity and in which phenological phase it occurs. In this sense, searching for varieties of plants that are tolerant to drought stress is still the best alternative to agricultural production maintenance, seeking for better crop performance and stability (SOUZA et al., 2015).

In accordance with Forsthofer et al. (2006), evaluations of corn grain yield potentials at different management levels and in various sowing times assists in identifying the limiting environmental factors in each season. Based on this knowledge, management strategies can be devised, enabling the adoption of feasible recommendations to minimize or even overcome weaknesses. By the definition of proper managements and suitable sowing times, farmers can optimize the use of existing resources on farm, maximizing gross income, besides protecting the environment.

With new improved cultivars being launched into the market, new management strategies are required to increase corn yields, such measures would be to narrow spacing between rows and consequent increase in plant stand. Nevertheless, one of the major emerging issues is related to inconsistent behavior of corn hybrids against environmental changes, which is expressed by the interaction between genotypes and environments. This interaction has a key role when recommending a new cultivar; thus, effects should be mitigated by identifying cultivars with higher phenotypic stability
(CARVALHO et al., 2002). Hence, researches have focused on improved cultivar adaptations to soil and climate conditions at diverse regions (LOPES et al., 2007; SOUZA et al., 2015).

The expression of plant traits is linked to genetic control, the environment and the interaction between both aspects. The responses of genotypes, under different environmental conditions, reduce correlations between phenotypic and genotypic values, hindering selection and recommendation of adapted and stable genotypes. There are several theories to evaluate plant adaptability and stability, among them the GGE biplot model (genotype main effects + genotype environment interaction), which considers the main genotype effect plus the interaction genotype $\mathrm{x}$ environment (YAN; HOLLAND 2010; SILVA; BENIN, 2012).

Given the above, the current study aimed at assessing adaptability and stability of corn hybrids grown in three sowing seasons in the city of Ceres-Go, Brazil.

\section{MATERIAL AND METHODS}

Experiments were carried at outbuildings of an Experimental Farm in the IF Goiano - Campus Ceres, which is located in the city of Ceres, Goiás state. The area lies at $15^{\circ} 21^{\prime} 02^{\prime \prime}$ south latitude, $49^{\circ}$ $35^{\prime} 36^{\prime \prime}$ west longitude and at altitude of $564 \mathrm{~m}$, in a land under no-tillage system. Rainfall distribution data are shown in Figure 1.

Soil samples were collected to evaluate soil fertility in the experimental area. They were collected at a depth of $0-20 \mathrm{~cm}$, showing the following results: $\mathrm{Ca}=2.4\left(\mathrm{cmol}_{\mathrm{c}} \mathrm{dm}^{-3}\right) ; \mathrm{Mg}=1.3$ $\left(\mathrm{cmol}_{\mathrm{c}} \mathrm{dm}^{-3}\right) ; \mathrm{Al}=0.0\left(\mathrm{cmol}_{\mathrm{c}} \mathrm{dm}^{-3}\right) ; \mathrm{H}=3.5\left(\mathrm{cmol}_{\mathrm{c}}\right.$ $\left.\mathrm{dm}^{-3}\right) ; \mathrm{P}=5.6\left(\mathrm{mg} \mathrm{dm}^{-3}\right) ; \mathrm{K}=101.0\left(\mathrm{mg} \mathrm{dm}^{-3}\right) ; \mathrm{pH}=$ $5.0\left(\mathrm{CaCl}_{2}\right)$; base saturation $51.80 \%$ and O.M. $=1.5$ $\mathrm{g} \mathrm{kg}^{-1}$.

Seven days before sowing, weeds were desiccated with $3 \mathrm{~L} \mathrm{ha}^{-1}$ glyphosate. Sowing was made on November 18, 2011; January 31, 2012 and February 20, 2012. Table 1 shows the traits of each of the ten hybrids (Truck, Fórmula P30F53, P3646H, P30F35H, AGN 30A77H, AGN 30A37H AG 8088PRO, DKB 390 and DKB Bi9440). Before being sown, seeds were treated with thiamethoxam + fipronil. The plant stand was 65,000 plants $\mathrm{ha}^{-1}$ in all treatments. Spacing between rows was $0.50 \mathrm{~m}$. Sowing fertilization was made with $20 \mathrm{~kg} \mathrm{ha}^{-1}$ nitrogen, $150 \mathrm{~kg} \mathrm{ha}^{-1}$ phosphorus and $80 \mathrm{~kg} \mathrm{ha}^{-1}$ potassium (04-30-16 formulation). Topdressings were held at fifth leaf stage by spreading $40 \mathrm{~kg} \mathrm{ha}^{-1}$ nitrogen and $40 \mathrm{~kg} \mathrm{ha}^{-1}$ potassium (20-00-20); and at eighth stage, applying $90 \mathrm{~kg} \mathrm{ha}^{-1}$ nitrogen (urea). Atrazine herbicide was applied in post-emergence at a dose of $3 \mathrm{~L} \mathrm{ha}^{-1}$ at sixth leaf stage. 


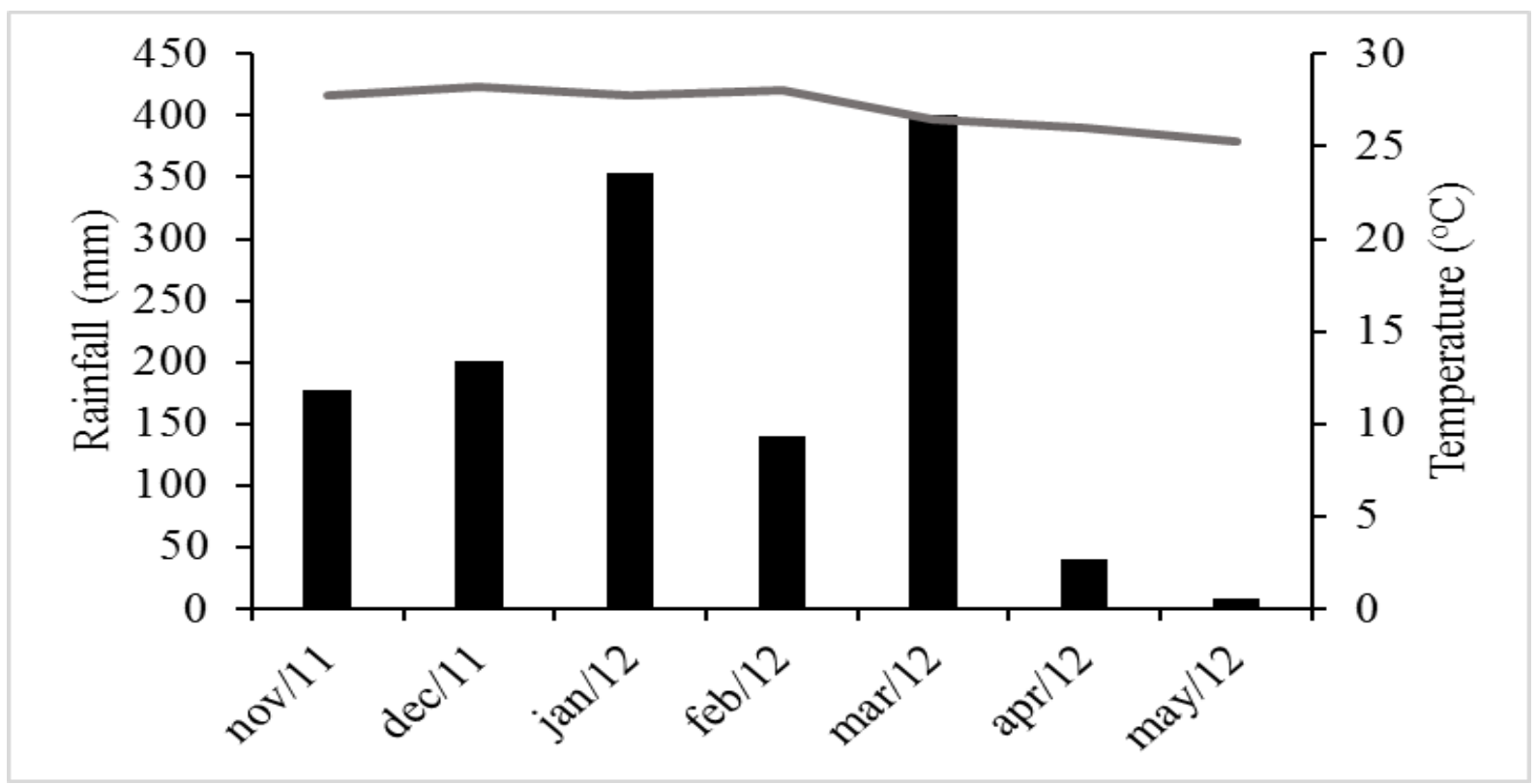

Figure 1. Averages of rainfall and temperature throughout the experimental period. Source: weather station from the IF Goiano Campus Ceres.

Table 1. Characteristics of the assessed hybrids.

\begin{tabular}{lcccc}
\hline Hybrid & Grain texture & Grain color & Cycle & Company \\
\hline Truck & Hard & Orange & Early & Syngenta \\
Fórmula & Semi-hard & Orange & Semi-early & Syngenta \\
P30F53 & Semi-hard & Orange & Early & Pioneer \\
P3646H & Semi-hard & Yellowish & Early & Pioneer \\
P30F35 H & Semi-hard & Orange & Early & Pioneer \\
AGN 30A77 & Semi-hard & Yellow & Early & Morgan \\
AGN 30A37 & Semi-hard & Yellow & Super-early & Morgan \\
Ag 8088 PRO & Semi-hard & Orange & Early & Agroceres \\
DKB 390Y & Semi-hard & Orange & Early & Dekalb \\
DKB bi9440 & Semi-hard & Yellow & Early & Dekalb \\
\hline
\end{tabular}

Source: manufacturing companies of the hybrids.

The experimental design was randomized blocks, evaluating ten hybrids (Truck, Fórmula, P30F53, P3646H, P30F35H, AGN 30A91H, AGN 30A37H, AG 8088VTPRO, DKB 390 and DKB Bi9440) in three sowing seasons (Nov. 18, 2011; Jan. 31, 2012 and Feb. 20, 2012), with three replications.

Four planting rows were sown along the experiment edges to provide a border effect. Each plot consisted of two 5-m rows, which were harvested disregarding $0.50 \mathrm{~m}$ edges on boh sides. The harvests were held on April 04, 2012; June 10, 2012 and July 1, 2012; respectively, for the three sowing dates.

After harvesting, ears were dehusked and threshed, using a manual thresher. Then, kernels were weighed on a digital scale and the moisture of each plot was adjusted to $13 \%$, calculating thus corn yields in $\mathrm{kg} \mathrm{ha}^{-1}$.

The grain yield data underwent variance analysis (individual and joint) and the means were compared by Scott-Knott testing at 5\% significance level. We also performed a graphical analysis comparing the hybrids and environments to assess each hybrid stability and adaptability, using the GGE Biplot method (FRUTOS et al. 2013). The statistical analysis were accomplished using the $\mathrm{R}$ software (R DEVELOPMENT CORE TEAM, 2014) with "easyanova" package (ARNHOLD, 2013).

\section{RESULTS AND DISCUSSION}

The three experiments were jointly evaluated (three sowing dates), since the relationship between the highest and lowest crop residue of the individual analyzes was 2.77 (Table 2). For Cruz et al. (2004), joint analysis of experiments can be performed when the ratio highest/ lowest crop residue does not exceed 7: 1 .

The variation coefficient of joint analysis was $14 \%$. In accordance with Scapim et al. (1995), variation coefficients between 10 to $22 \%$ are considered average values. However, there was greater variations in experiments where water deficit was higher, with values ranging of 9,16 and $23 \%$ for the sowing dates of Nov. 18, 2011; Jan. 31, 2012 and Feb. 20, 2012, respectively. 
Table 2. Overview of the variance analysis for grain yield $\left(\mathrm{kg} \mathrm{ha}^{-1}\right)$ of ten corn hybrids under three contrasting seasons regarding water availability in the north cerrado of Goiás state, in Brazil.

\begin{tabular}{lrrr}
\hline V.F. & D.F. & M.S. & P-value \\
\hline Hybrids & 9 & 4699965 & $<0.001$ \\
Seasons & 2 & 281510034 & $<0.001$ \\
Hybrids x Seasons & 18 & 2793441 & $<0.001$ \\
Blocks/ Seasons & 6 & 866041 & 0.0621 \\
Residue & 54 & 402343 & \\
\hline Joint analysis C.V. (\%) & 14 & & \\
Individual analysis residue in season 1 & 549738 & \\
Individual analysis residue in season 2 & 458504 & \\
Individual analysis residue in season 3 & 198788 & \\
Highest/ lowest residue ratio & 2.77 & \\
Season 1 C.V. (\%) & 9 & \\
Season 2 C.V. (\%) & 16 & \\
Season 3 C.V. (\%) & 23 & \\
Shapiro-Wilk p-value in residues & \multicolumn{2}{c}{0.8238} & \\
\hline
\end{tabular}

The significant interaction between hybrids and seasons suggested that hybrids performed inconsistently across the three periods, i.e. there were changes in the means of corn hybrids (Table 2). Accordingly, these hybrids were individually evaluated at each sowing time, since their yield was variable (Table 3), indicating that each genotype has a distinct performance at each season. This indicates that the recommendation of a certain hybrid determined for different sowing dates in a generalized way can be misleading; therefore, regional results should also be considered, otherwise cultivars of most stable productive behavior have to be selected to face the environmental variations (OLIVEIRA et al., 2004). According to Souza et al. (2015), hybrids feature different behavior as they are subjected to varied water deficits due to the genetic variability among cultivars.

In the statistical breakdown of hybrids into the environments, means of AGN $30 \mathrm{~A} 77 \mathrm{H}$ were superior on Nov. 18, 2011 and Jan. 31, 2012 (Table 3). However, on Feb. 20, 2012, when occurred the highest drought, the hybrids showed no statistically significant difference.

Table 3. Grain yield averages $\left(\mathrm{kg} \mathrm{ha}^{-1}\right)$ for ten corn hybrids under three contrasting seasons regarding water availability in the north cerrado of Goiás state, Brazil.

\begin{tabular}{lcll}
\hline \multirow{2}{*}{ Hybrids } & \multicolumn{3}{c}{ Sowing date $^{1}$} \\
\cline { 2 - 4 } Truck & Nov. 18, 2011 & Jan. 31, 2012 & Feb. 20, 2012 \\
Fórmula & $8448 \mathrm{Ac}$ & $3872 \mathrm{Bb}$ & $2260 \mathrm{Ca}$ \\
P30F53 & $9724 \mathrm{Ab}$ & $4479 \mathrm{Bb}$ & $1571 \mathrm{Ca}$ \\
P3646H & $8184 \mathrm{Ac}$ & $3960 \mathrm{Bb}$ & $1637 \mathrm{Ca}$ \\
P30F35H & $7656 \mathrm{Ac}$ & $4796 \mathrm{Bb}$ & $2219 \mathrm{Ca}$ \\
AGN 30A77H & $5975 \mathrm{Ad}$ & $4224 \mathrm{Bb}$ & $2736 \mathrm{Ca}$ \\
AGN 30A37H & $10959 \mathrm{Aa}$ & $6336 \mathrm{Ba}$ & $1475 \mathrm{Ca}$ \\
AG 8088 PRO & $8272 \mathrm{Ac}$ & $4180 \mathrm{Bb}$ & $1766 \mathrm{Ca}$ \\
DKB 390 & $6726 \mathrm{Ad}$ & $2590 \mathrm{Bc}$ & $2171 \mathrm{Ba}$ \\
DKB Bi9440 & $7260 \mathrm{Ad}$ & $3916 \mathrm{Bb}$ & $2378 \mathrm{Ca}$ \\
\hline
\end{tabular}

${ }^{1}$ means followed by the same lowercase letter within the column and uppercase within line are statistically similar by the Scott-Knott's test.

Sowing on Nov. 18, 2011 reached most favorable results likely because water was properly supplied meeting crop requirements (Figure 1). Similarly, we can infer that low yields on Feb. 20, 2012 are related to poor water availability, which was one of the major yield-reduction factors (Figure 1). Moreover, another factor that may be related to such low yields in this season is temperature (Figure 1), which have reduced and may have generated losses on productive potential of 
hybrids. According to Paula et al. (2010), climate and soil changes cause varied responses in each genotype. In this research, soil type was the same for the three sowing dates, and plots were allocated side by side. As a result, we can infer that climatic factors, particularly drought and temperature, in addition to genetic differences of the hybrids were the parameters influencing crop performance
(Table 3).

Figure 2 illustrates the superiority of AGN $30 \mathrm{~A} 77 \mathrm{H}$ on Nov. 18, 2011, reaching a yield of $10,959 \mathrm{~kg} \mathrm{ha}^{-1}$ (Table 3), and on Jan. 31, 2012, compared to the other seasons. In contrast, sowing on Feb. 20, 2012 may be considered unfavorable due to drought, as shown in Figure 1, resulting in poor performance of all hybrids.

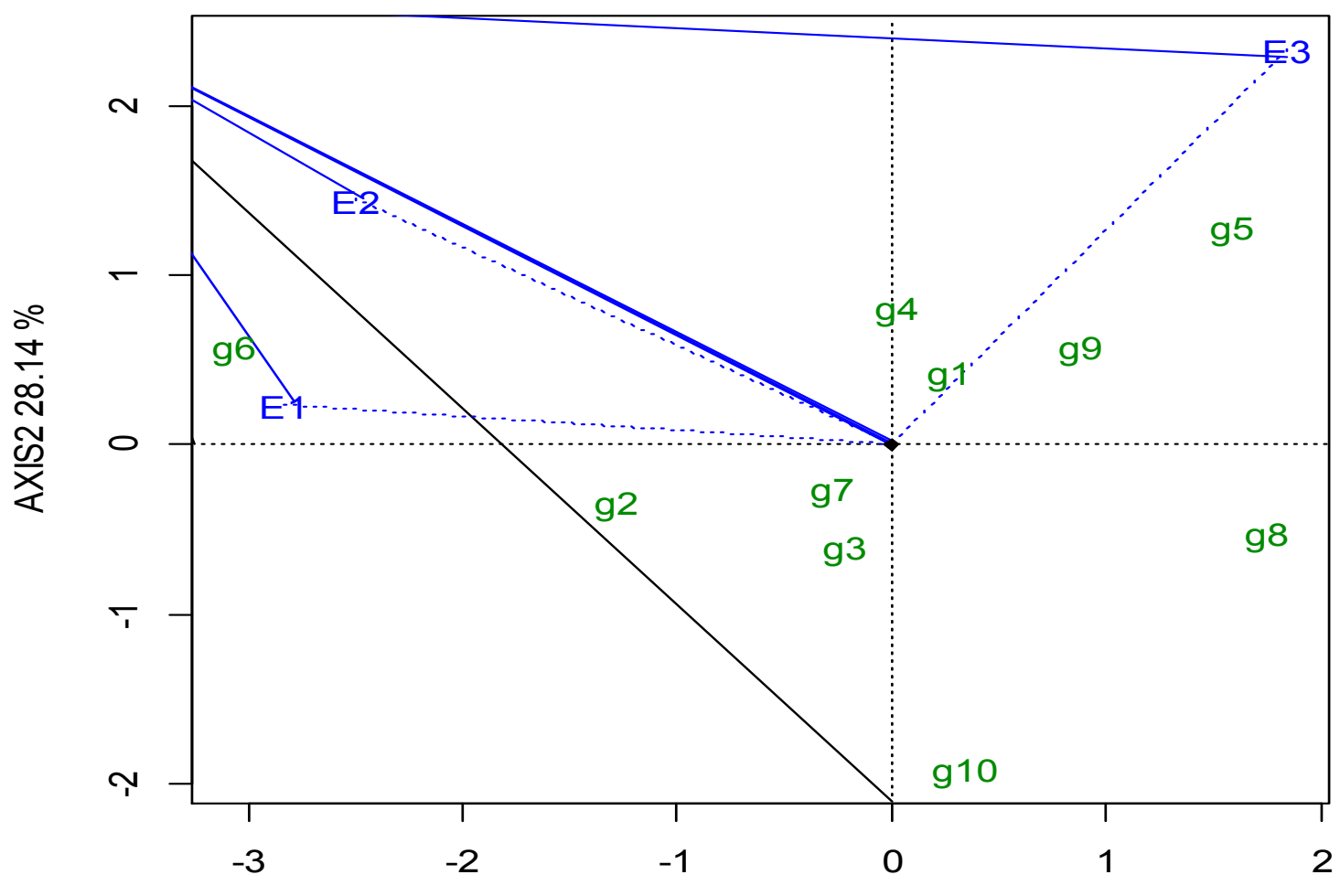

AXIS1 $65.46 \%$

Figure 2. GGEBiplot graph with a view of hybrids ( $\mathrm{g} 1=$ Truck, g2=Fómula, g3=P30F53, g4=P3646H, g5=P30F35H, $\mathrm{g} 6=\mathrm{AGN} 30 \mathrm{~A} 77 \mathrm{H}, \mathrm{g} 7=\mathrm{AGN} 30 \mathrm{~A} 37 \mathrm{H}, \mathrm{g} 8=\mathrm{AG} 8088 \mathrm{PRO}, \mathrm{g} 9=\mathrm{DKB} 390$ and $\mathrm{g} 10=\mathrm{DKB}$ Bi9440) in three distinct sowing dates [E1 (Nov. 18, 2011), E2 (Jan. 31, 2012) and E3 (Feb. 20, 2012)].

By the two-dimensional graphics obtained via GGE Biplot method (Figures 2,3,4 and 5), we can assert that the hybrid AGN $30 \mathrm{~A} 77 \mathrm{H}$ (g6) has increased adaptability on Nov. 18, 2011 and on Jan. 31, 2012, followed by hybrid Fórmula (g2). Yet the hybrid $\mathrm{P} 30 \mathrm{~F} 35 \mathrm{H}$ (g5) reaches a better performance when sown on Feb. 20, 2012. Hence, AGN 30A77H (g6) owns a higher adaptive capacity, which as stated by Camargo-Buitrago et al. (2011) is a crucial factor plant breeding programs.
As shown in Figures 2, 3, 4 and 5, the lowest yields were achieved for P30F35H (g5) on Nov. 18, 2011, for AG 8088 VTPRO (g8) on Jan. 31, 2012, and DKB bi9440 (g10) on Feb. 20, 2012. These data can also be verified in Table 3 .

The hybrid AGN $30 \mathrm{~A} 37 \mathrm{H}$ (g7) showed the best stability as it is closest to the center of the biplot (SILVA, BENIN, 2012), while the DKB bi9440 (g10) was the least stable, as shown in Figures 2,3,4 and 5 . 


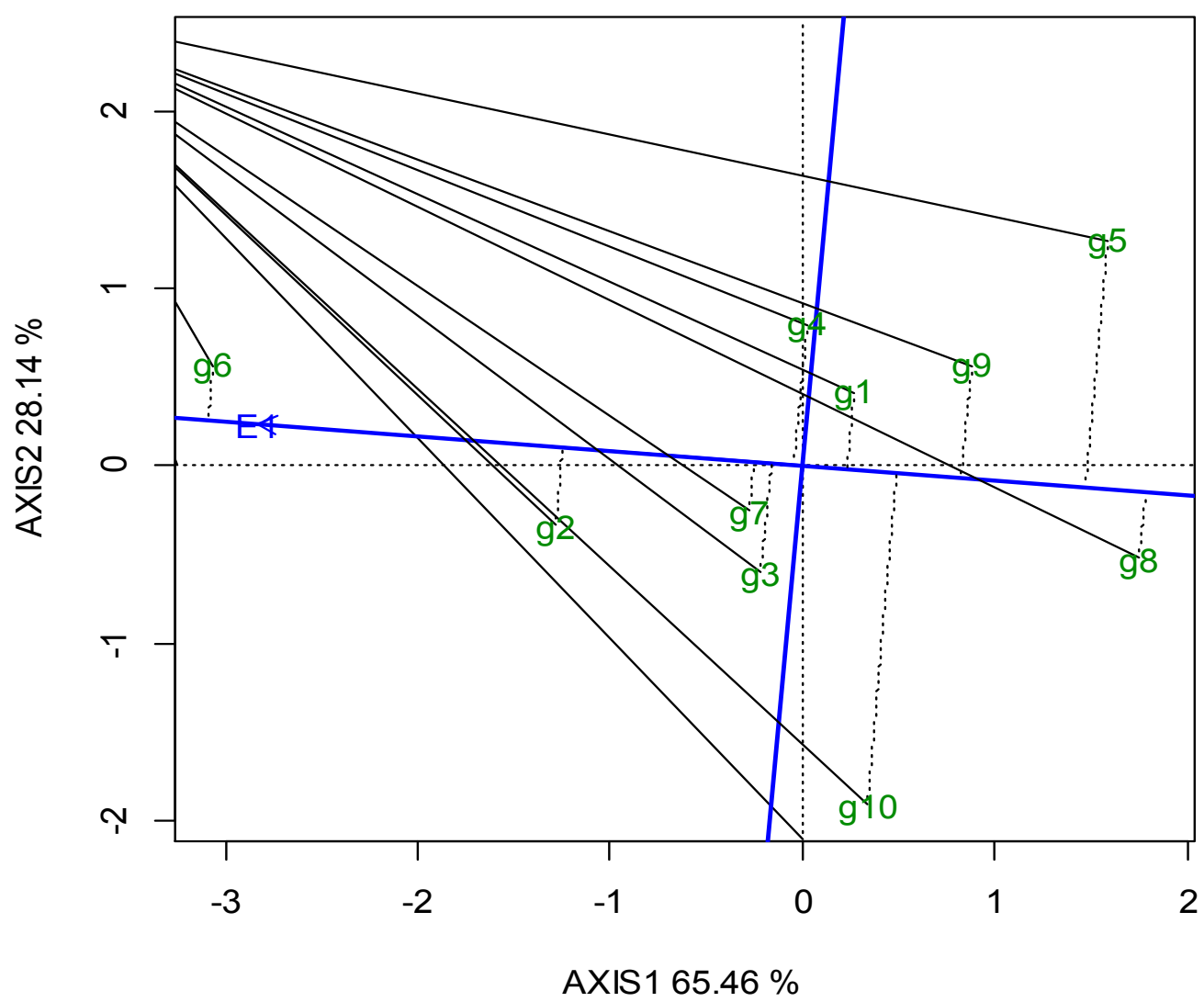

Figure 3. GGEBiplot graph with a view of hybrids $(\mathrm{g} 1=$ Truck, g2=Fómula, g3=P30F53, g4=P3646H, g5=P30F35H, $\mathrm{g} 6=\mathrm{AGN} 30 \mathrm{~A} 77 \mathrm{H}, \mathrm{g} 7=\mathrm{AGN} 30 \mathrm{~A} 37 \mathrm{H}, \mathrm{g} 8=\mathrm{AG} 8088 \mathrm{PRO}, \mathrm{g} 9=\mathrm{DKB} 390$ and $\mathrm{g} 10=\mathrm{DKB}$ Bi9440) on Nov. 18, 2011 (E1).

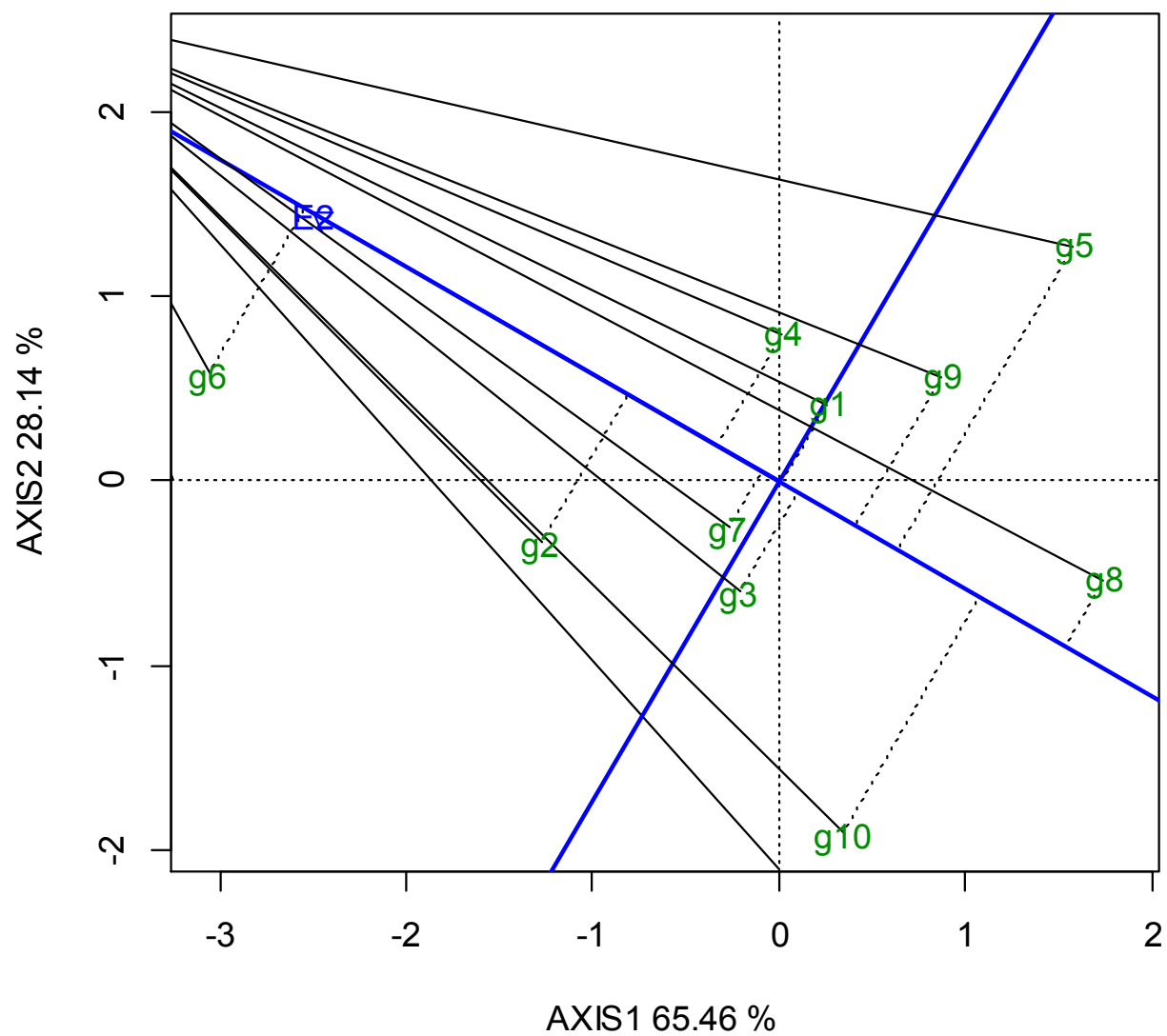

Figure 4. GGEBiplot graph with a view of hybrids ( $\mathrm{g} 1=$ Truck, g2=Fómula, g3=P30F53, g4=P3646H, g5=P30F35H, g6=AGN 30A77H, g7= AGN 30A37H, g8=AG 8088 PRO, g9=DKB 390 and g10=DKB Bi9440) on Jan. 31, 2012 (E2). 


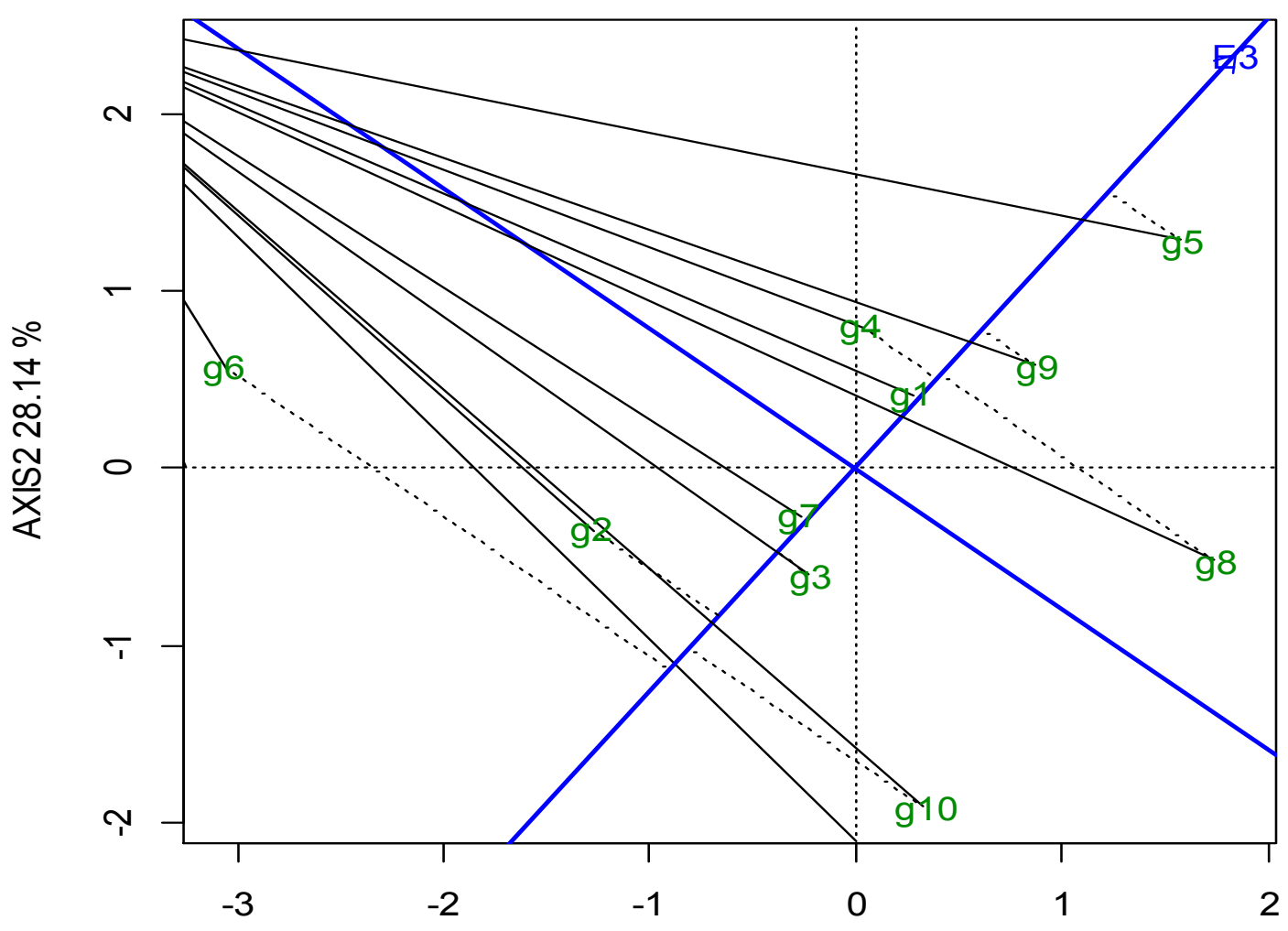

AXIS1 $65.46 \%$

Figure 5. GGEBiplot graph with a view of hybrids ( $\mathrm{g} 1=$ Truck, $\mathrm{g} 2=$ Fómula, g3=P30F53, g4=P3646H, g5=P30F35H, g6=AGN 30A77H, g7= AGN 30A37H, g8=AG 8088 PRO, g9=DKB 390 and g10=DKB Bi9440) on Feb. 20, 2012 (E3).

\section{CONCLUSIONS}

The hybrid AGN 30A77H is best suited for summer sowing (Nov. 18, 2011) and interim-harvest in the end of January (Jan. 31, 2012).

The hybrid $\mathrm{P} 30 \mathrm{~F} 35 \mathrm{H}$ has great performance late interim-harvest (Feb. 20, 2012) in February.

\section{ACKNOWLEDGEMENTS}

The authors want to thank the following companies: Irriplan (Syngenta), Herbicampo (Pioneer), Terra Viva (Morgan), Futura (Agroceres) and Uruagro (Dekalb) for donating the seeds of the hybrids used in this research, and thank the IF Goiano Campus Ceres for the support and provision with inputs.

\section{REFERENCES}

ARNHOLD, E. Package in the $\mathrm{R}$ environment for analysis of variance and complementary analyses. Brazilian Journal Veterinary Reseach Animal Science, São Paulo, v. 50, n. 6, p. 488-492, 2013.

BRASIL. Companhia Nacional de Abastecimento.
Acompanhamento da safra brasileira de Grãos. Disponível em: <http://www.conab.gov.br/ OlalaCMS/uploads/ arquivos/15_09_11_10_42_03_boletim_graos_setembro 2015.pdf $>$. Acesso em: $\overline{2} 4$ mar. 2016.

CAMARGO-BUITRAGO, I. et al. Identificación de megaambientes para potenciar el uso de genótipos superiores de arroz en Panamá. Pesquisa Agropecuária Brasileira, Brasília, v. 46, n. 9, p. 1601-1069, 2011.

CARVALHO, H. W. L. et al. Adaptabilidade e estabilidade de híbridos de milho em diferentes condições ambientais do Nordeste Brasileiro. Revista Brasileira de Milho e Sorgo, Sete Lagoas, v. 1, n. 2, p. 75-82, 2002.

CRUZ, C. D.; REGAZZI, A. J.; CARNEIRO, P. C. S. Modelos biométricos aplicados ao melhoramento genético. 3. ed. Viçosa, MG: 2004. $480 \mathrm{p}$.

FORSTHOFER, E. L. et al. Desempenho agronômico e econômico do milho em diferentes níveis de manejo e épocas de semeadura. Pesquisa Agropecuária Brasileira, Brasília, v. 41, n. 3, p. 399-407, 2006. 
FRUTOS, E.; GALINDO, M. P.; LEIVA, V. An interactive biplot implementation in $\mathrm{R}$ for modeling genotype-by-environment interaction. Stochastic Environmental Research and Risk Assessment, Berlin, v. 28, n. 7, p. 1629-1641, 2014.

LOPES, S. J. et al. Relações de causa e efeito em espigas de milho relacionadas aos tipos de híbridos. Ciência Rural, Santa Maria, v. 37, n. 6, p. 1536-1542, 2007.

OLIVEIRA, J. S. et al. Estratificação de ambientes, adaptabilidade e estabilidade de híbridos comerciais de milho para silagem no sul do Brasil. Ciência Rural, Santa Maria, v. 34, n. 4, p. 997-1003, 2004.

PAULA, T. O. M. et al. Pi statistics underlying the evaluation of stability, adaptability and relation between the genetic structure and homeostasis in popcorn. Acta Scientiarum: Agronomy, Maringá, v. 32 , n. 2, p. 269-277, 2010.

R. Development core team: A language and environment for statistical computing. R Foundation for Statistical Computing, Vienna. Disponível em: <http://www.R-project.org/>. Acesso em: 03 mar. 2014.

SCAPIM, C. A.; CARVALHO, C. G. P.; CRUZ, C. D. Uma proposta de classificação dos coeficientes de variação para a cultura do milho. Pesquisa Agropecuária Brasileira, Brasília, v. 30, n. 5, p. 683-686, 1995.

SILVA, R. R.; BENIN, G. Análises biplot: conceitos, interpretações e aplicações. Ciência Rural, Santa Maria, v. 42, n. 8, p. 1404-1412, 2012

SOUZA, R. S. et al. Desempenho produtivo de genótipos de milho sob déficit hídrico. Revista Brasileira de Milho e Sorgo, Sete Lagoas, v. 14, n. 1, p. 49- 60, 2015.

TOLLENAAR, M.; LEE, E. A. Yield potential, yield stability and stress tolerance in maize. Field Crops Research, Amsterdan, v. 75, n. 2, p. 161-169, 2002.

UNITED STATES. United States Department of Agriculture. Data and Statistics: Foreign Agricultural Service. Available in: <http://www.usda.gov/ wps/portal/usda/usdahome?

navid=DATA_STATISTICS $>$. Access in: 10 mar. 2014.

YAN, W.; HOLLAND, J. B. A heritability-adjusted GGE biplot for test environment evaluation. Euphytica, Wageningen, v. 171, n. 3, p. 355- 369, 2010. 